\title{
James Edward Crombie, M.A., LL.D.
}

James EDward CRombie was born in the parish of Old Machar in 1862. $\mathrm{He}$ was the son of John Crombie, an alumnus of Marischal College, 1833-1834, and the grandson of James Crombie, who founded a woollen manufacturing business at Cothal, near Aberdeen, towards the end of the eighteenth century. James Edward Crombie was educated in Old Aberdeen, became a student at King's College, and graduated Master of Arts in 1882. Thereafter he studied for a time in Germany, and on his return he entered the Grandholm Woollen Manufacturing Works, where, after a short time, he took an active part in the business. He was deeply interested in organisation and in craftsmanship, and was responsible in a large measure for the subsequent development of the business, of which he was a director for over thirty years.

Despite the claims of his business he found time to devote to public work and to other pursuits. He was deeply interested in folk-lore, and to further his studies of the subject acquired a good knowledge of French, Spanish, and German, as well as a serviceable knowledge of Italian and Russian. In pursuit of this interest he travelled widely in the more remote parts of Europe. He studied more particularly the ideas of primitive peoples in relation to death and burial; he also explored some aspects of their recreations and amusements, and had a considerable number of manuscripts dealing with these subjects.

He gave considerable attention to scientific subjects, more especially those connected with meteorology and seismology, and for many years had meteorological instruments and a seismograph installed near to his house, which he tended himself, taking continuous records. He was an active member of the Seismology Committee of the British Association for the Advancement of Science, and did a great deal for the promotion of the study of the subject in this country. For some years he contributed generously to the financial support of the work carried out for the Committee at the University of Oxford.

In addition to all these activities he took a prominent part in public affairs, both local and national. For many years he served on the boards. of the Sick Children's Hospital and of the Newhills Home, as well as on other kindred bodies. 
The University of Aberdeen is indebted to him for the services he rendered it, first as Rector's Assessor and later for a long period as Chancellor's Assessor, an office which he resigned this year, to the great regret of his colleagues. Only those who had the privilege of working with him can appreciate properly the value of his counsel, his unsparing devotion to every duty he undertook, and his ready and generous response with financial help to any object he thought deserving of his support, for the most part given anonymously.

He took an active part in politics, and it was his exertions during the autumn of 1931, in connection with the then impending general election, which were the immediate cause of his breakdown in health. Acting under medical advice he gave up most of his public work, and after a complete rest of some months he recovered his health. His friends were encouraged by this recovery to hope that he had many years of usefulness before him, but a recurrence of his trouble in the late summer of this year rendered these hopes vain. He died on the 6th of August 1932.

He was elected a Fellow of the Society in 1915.

H. M. M. 